de télékinésie, demandent quelques confirmations nouvelles. Mais quant à la télépathie, la lucidité (second sight), la cryptesthésie, la prémonition, tous phénomènes n'impliquant pas d'action physique matérielle, il y a des témoignages si abondants et si précis qu'on ne peut se refuser à les admettre. A moins qu'on ne fasse fi de la méthode expérimentale. C'est se diminuer que de ne pas les reconnaître, suivant la forte parole d'Oliver Lodge.

L'expérience est là pour établir, en toute certitude, qu'il y a, à la connaissance, d'autres voies que les voies sensorielles habituelles.

Et c'est tout ce que je puis admettre, jusqu'à présent, comme irrévocablement démontré. Mais c'est beaucoup déjà. L'existence de ce sixième sens est véritablement un monde nouveau qui s'ouvre à nous.

L'intelligence est atteinte par des forces qui lui vévèlent des faits que ni la vue, ni l'oü̈e, ni le toucher ne peuvent Iui faive connaître.

Alors, comme l'a dit mon illustre ami O. Lodge, deux hypothèses sont en présence. Ou bien ce sont des esprits, les âmes des défunts qui se manifestent à nous. Ou bien ce sont des vibrations (de nature inconnue) qui agissent sur notre organisme.

L'hypothèse des esprits est quelquefois très commode et s'adapte admirablement à certains faits; mais elle soulève des objections formidables. Je ne la repousse nullement. Pourtant je ne peux guère y croire et je ne la regarde que comme une hypothèse de travail.

L'hypothèse des 'vibrations (inconnues) me paraît préférable.

Après tout pourquoi ne pas supposer que la réalité émet des vibrations? Ne voyons-nous pas des vibrations innombrables et puissantes, comme les ondes hertziennes et les ondes magnétiques, qui ne sont décelées que par des détecteurs spéciaux, et qui sans ces détecteurs, passeraient inaperçues?

A vrai dire, je me préoccupe peu de ces hypothèses. Ce qui m'intéresse passionément, c'est la constatation des faits. Or il a été démontré par Crookes, Lodge, Myers, Sidgwick, et beaucoup d'autres, que l'intelligence humaine a parfois sur la réalité (très rarement, je le veux bien), des notions que les sens normaux ne peuvent lui donner. Tous ceux qui ont méthodiquement et sans préjugés étudié cette psychologie nouvelle ont été finalement forcés de l'admettre.

CHARLES RICHET.

\section{The Fluorescence of Superheated Mercury Vapour.}

IN a letter to NATURE (April $\mathrm{x} 7$, I926, p. 555) I gave a short report of experiments on the fluorescence of mercury vapour. The conclusion arrived at was that the total intensity of the visible fluorescence in saturated mercury vapour, as well as that of different bands and lines in the visible and ultra-violet part of the spectrum, is, for a given exciting light, a function of the temperature only. These results are in disagreement with those of $\mathrm{R}$. W. Wood and van der Lingen (Proc. Roy. Soc., 99, 362, I92I, and Astrophys. Jour., 54, I49, I92I). According to these authors the fluorescence can only be excited in freshly formed mercury vapour.

Further experiments, with various vessels containing mercury vapour and different kinds of exciting light, have fully confirmed my previous results. The fluorescence does not depend on whether the saturated mercury vapour is old or freshly formed.

These experiments suggest the possibility of exciting the fluorescence in the unsaturated mercury vapour. For this purpose some experiments have been carried out. An evacuated and sealed quartz NO. 298I, VOL. I I 8$]$ tube was used containing an amount of mercury just sufficient to fill the vessel with saturated vapour at about $240^{\circ} \mathrm{C}$. The vessel was heated in an electric furnace closed with quartz windows. The temperature was measured by a thermometer and a thermopile fixed to the walls of the tube in two different places. The fluorescence excited by a condensed aluminium spark was observed visually and the spectrum taken with a quartz spectrograph. With rising temperature the minute mercury droplets in the vessel disappear gradually. At about $240^{\circ} \mathrm{C}$. the last droplets vanish, the intensity of the fluorescence remaining unchanged. The intensity did not change either when the vessel was heated to $355^{\circ} \mathrm{C}$. or kept for several hours at some constant temperatures above $300^{\circ} \mathrm{C}$. The intensities of single bands and lines of the fluorescence spectrum remain likewise practically unchanged. The appearance of the spectrum is practically the same as in the case of saturated mercury vapour at about $240^{\circ} \mathrm{C}$., and this proves that above $240^{\circ} \mathrm{C}$., the vapour was really unsaturated. Indeed, for the saturated mercury vapour the line $2537 \AA$.U. would disappear at about $260^{\circ} \mathrm{C}$., and similarly the band situated on the long wave-length side of this line at about $280^{\circ} \mathrm{C}$.

Previous experiments have shown that with changing vapour density (by varying the temperature of the saturated vapour) the fluorescence changes. In the present experiments the vapour density above $240^{\circ} \mathrm{C}$. was constant and the fluorescence remained very nearly constant.

These results may be summed up by saying that for a given exciting light the fluorescence of the mercury vapour depends mainly on the density of the vapour. The age of the vapour is of no importance. HENRYK NIEWODNICZAŃSKI.

Stefan Batory University,

Wilno, Poland, October 8.

\section{Dr. Jeans and the 'Disease' of Life.}

Dr. Jeans can see after himself, I feel sure; and if he accepts the statement of the writer of the note on his address in NATURE of December 4, p. 8I2, that in his view life is "possibly merely a disease infesting the rubbish heap in the corner " of the universe, no other interpretation can live. But as a student of life I was on the point of writing to thank Dr. Jeans not only for his masterly address, but also, most of all, for his stately and hopeful close wherein no such opinion as the above was fathered by him. Readers of NATURE can turn to the original in the Supplement to the issue of December 4 and judge for themselves. Dr. Jeans put two interpretations, in two different ways, and his final brace were: Is life of the nature of a disease which affects matter in its old age, or is it the only reality, which creates, instead of being created by ? The writer of the paragraph takes the first only and fixes it as Dr. Jeans's own view. Why?

It is probably of no importance to anybody but myself to say that I welcomed the second, and have long taken it, for the simple, and I suggest scientific, reason, among many others, that matter as I see it cannot apprehend or understand me, and that $I$ at least am able to apprehend it. I do not see why the apprehender should be subordinate to the apprehended, which, whatever its volume, does not apprehend anything, not even itself. J. J. RoBINSON.

Barnham, Sussex.

Mr. RoBInson's letter reveals a misapprehension which might be shared by others, and should at once be removed. The note in question was not an independent report of Dr. Jeans's article. It was a 